\title{
REVIEW
}

\section{Nutritional and immunological importance of colostrum for the new-born pig}

\author{
J. LE DIVIDICH ${ }^{1}$, J.A. ROOKE ${ }^{2 *}$ AND P. HERPIN ${ }^{3}$ \\ ${ }^{1}$ INRA UMR-SENAH, 35590 St Gilles, France \\ ${ }^{2} S A C$, Sustainable Livestock Systems, Craibstone Estate, Aberdeen AB21 9YA, UK \\ ${ }^{3}$ INRA, Department of Animal Physiology and Livestock Systems, 35590 St-Gilles, France
}

(Revised MS received 5 July 2005)

\begin{abstract}
SUMMARY
The nutritional and immunological importance of colostrum for the survival and development of the neonatal pig are reviewed. The pig is born with low body energy stores and devoid of serum immunoglobulins. Colostrum provides the piglet with both energy and maternal antibodies but its fat and protein composition is very variable. Colostrum is very digestible, and both colostral energy and nitrogen $(\mathrm{N})$ are retained with a very high efficiency. Colostrum production by the sow assessed from the weight gain of the litter from birth to $24 \mathrm{~h}$ of age is very variable (from 1900 to $5300 \mathrm{~g}$ ). There is no clear effect of litter size or parity, suggesting that colostrum production is a characteristic of the sow. Within a litter, colostrum consumption by the individual piglets varies considerably. It is independent of birth order, but related positively to birth weight and negatively to litter size. Other factors influencing colostrum consumption, including cold stress, premature birth and birth hypoxia, are discussed. Because of the epitheliochorial nature of the porcine placenta, the new-born piglet must acquire maternal immunoglobulin $\mathrm{G}(\mathrm{IgG})$ from ingested colostrum for passive immune protection until the immune system of the piglet becomes fully developed. Colostrum IgG concentrations in milk vary widely between individual sows both in initial concentration and in the rate at which concentrations decline during the first $24 \mathrm{~h}$ of life. The piglet can only absorb intact IgG prior to gut closure, which occurs in the first $24 \mathrm{~h}$ of life and is induced by intakes of colostrum which are insufficient to maintain piglet live-weight. As a result, the amounts of intact IgG absorbed by the piglet vary widely. The effects of colostrum consumption on neonatal survival are discussed. Consumption of colostrum in amounts sufficient to meet the energy requirement of the piglet is a major determinant for survival. Since most neonatal losses occur in the first 2 days of life, before acquisition of a maternal IgG for immune protection becomes important for survival, piglet serum IgG concentration does not correlate well with early survival but is important in later resistance to disease challenge. It is concluded that colostrum production is a good marker for the maternal quality of the sow. Future research should focus on the ability of the sow to produce more colostrum and on the possible delayed effects of passive immunisation on the health and performance of piglet at weaning and later in life.
\end{abstract}

\section{INTRODUCTION}

In all mammals, the perinatal period is attended by important modifications to several physiological functions associated with abrupt changes in energy metabolism and nutrition. In common with most farm animals, the piglet is born with low energy

* To whom all correspondence should be addressed. Email: John.Rooke@sac.ac.uk reserves and devoid of immune protection. At birth, the new-born is exposed to pathogens and a cold environment, and hence must acquire immune protection, activate the mechanisms responsible for heat production and supply energy to its heat-producing tissues. From a nutritional standpoint, the fetus receives a continuous intravenous supply of substrates, mainly as glucose, for growth and metabolism. After birth, the pig is fed at intervals first with colostrum 
and then with milk, which are high in fat and low in carbohydrate, implying that the intestine must be functional at birth and the piglet rapidly able to synthesize glucose by gluconeogenesis to supply its glucose-dependent tissues and to oxidize fats. In this context ingestion of colostrum, which provides both energy and maternal antibodies that protect the piglets until their own immune system matures, is of the utmost importance for survival while also being the continuation of the mother-infant bond. However, in a polytocous species such as the pig, competition among siblings of variable birth weight for access to colostrum is intense and failure to achieve a regular and sufficient intake of colostrum is a major cause underlying production losses.

In recent years, several reviews have been devoted to the neonatal pig, including the development of its energy metabolism and thermoregulatory mechanisms (Herpin et al. 2005), its digestive function (Cranwell 1995; Xu et al. 2002), while factors associated with peri- and post-natal mortality have been the subject of a special issue of Livestock Production Science (2002). The present review is devoted specifically to colostrum. However, a complete discussion of the subject is beyond the scope of a single paper. The physiological importance of colostrum in the development of the gastrointestinal tract, the stimulation of some metabolic pathway (for example, gluconeogenesis), or as the only source of fat for the new-born piglet has been reviewed recently (Xu et al. 2002; Herpin et al. 2005) and hence will not be considered in the present paper which will consider the nutritional and immunological roles of colostrum in the new-born pig. These two aspects have been selected because of their marked involvement in piglet survival.

\section{NUTRITIONAL IMPORTANCE OF COLOSTRUM}

\section{Energy requirement of the new-born piglet}

As a growing animal, the neonatal pig needs energy to meet its requirements for maintenance, including thermoregulation and physical activity, and growth. Requirements for energy and nutrients, expressed on a body-weight (BW) basis, are maximal at birth. Estimated under conditions of thermal neutrality and of minimum energy expenditure associated with feeding (i.e. tube- or bottle-feeding) and physical activity, the energy required for maintenance is $275 \mathrm{~kJ} / \mathrm{kg}$ BW (Le Dividich et al. 1994; Marion \& Le Dividich 1999). In practice, however, the new-born pig experiences a period of cold stress and the extra energy required for thermoregulation averages $2 \mathrm{~kJ} / \mathrm{kg} \mathrm{BW} /$ $\mathrm{h} /{ }^{\circ} \mathrm{C}$ below the lower critical temperature, a value $2 \cdot 6$ times higher than at weaning (Le Dividich et al. 1998). The energy cost of standing is $9 \cdot 5 \mathrm{~kJ} / \mathrm{kg} \mathrm{BW} / \mathrm{h}$ and the minimal energy expenditure associated with physical activity is $105 \mathrm{~kJ} / \mathrm{kg} \mathrm{BW}$ during the first day of life (Le Dividich et al. 1994). Body weight gain during the first postnatal day, and the amounts of energy and protein accreted are very variable. In a study involving 20 litters (258 piglets), BW gain between birth and $24 \mathrm{~h}$ after birth of piglets that survived to weaning averaged $70 \pm 67$ (S.D.) g/ $\mathrm{kg} \mathrm{BW}$ (J. Le Dividich, F. Thomas \& G. P. Martineau, personal communication). On the basis that the energy content of the corresponding empty BW gain is $6 \mathrm{~kJ} / \mathrm{g}$, accreted energy averages $300 \mathrm{~kJ}$ and may be as high as $800 \mathrm{~kJ}$ if the top 0.1 in terms of liveweight gain are considered. Overall, in thermoneutral conditions, the minimum net energy requirement for survival of a $1.0 \mathrm{~kg}$ piglet is approximately $700 \mathrm{~kJ}$ during the first postnatal day, and may be as high as 900-950 kJ in moderately cold conditions (Fig. 1). This energy requirement is met from both body energy reserves and colostrum since the first suckling occurs usually some $10-30 \mathrm{~min}$ after birth.

\section{Energy reserves at birth}

These reserves provide an immediate source of energy at birth. Major body constituents which can potentially be used as energy-yielding substrates are protein, glycogen and fats. However, body protein catabolism occurs at a very low rate during the neonatal period, accounting for only a small proportion of thermoneutral fasting heat production (Le Dividich et al. 1994). Total body glycogen stores range from $30-38 \mathrm{~g} / \mathrm{kg}$ BW at birth. The glycogen reserves are rapidly depleted. In conventional environmental conditions, 0.75 of liver glycogen and 0.41 of muscle glycogen are utilized by $12 \mathrm{~h}$ postpartum (Elliot \& Lodge 1977), and a cold environment hastens the depletion rate in both tissues. The total amount of fat in the new-born pig is very low, ranging from $10-20 \mathrm{~g} / \mathrm{kg} \mathrm{BW}$. In addition, the pig lacks brown adipose tissue, as indicated by the immuno-blotting studies of Trayhurn et al. (1989), who showed that piglets do not express uncoupling protein 1 in adipose tissue. A large proportion $(0 \cdot 45)$ of fat is structural fat and not available for mobilization. Although very limited placental transfer of fatty acids does occur during late gestation (Rooke et al. 1998), attempts to improve energy stores do not usually result in substantial increases in fat and glycogen. In addition, selection of pigs for reduced carcass fatness has resulted in pigs which are leaner at birth (Herpin et al. 1993) and have lighter livers and less liver glycogen (Canario et al. 2005). Overall, available energy derived from glycogen and fat is low (Fig. 1), amounting to about $420 \mathrm{~kJ} / \mathrm{kg} \mathrm{BW}$, which accounts for less than $0 \cdot 10$ of that found in the newborn infant (Mellor \& Cockburn 1986). It does not meet the energy required for maintenance and 


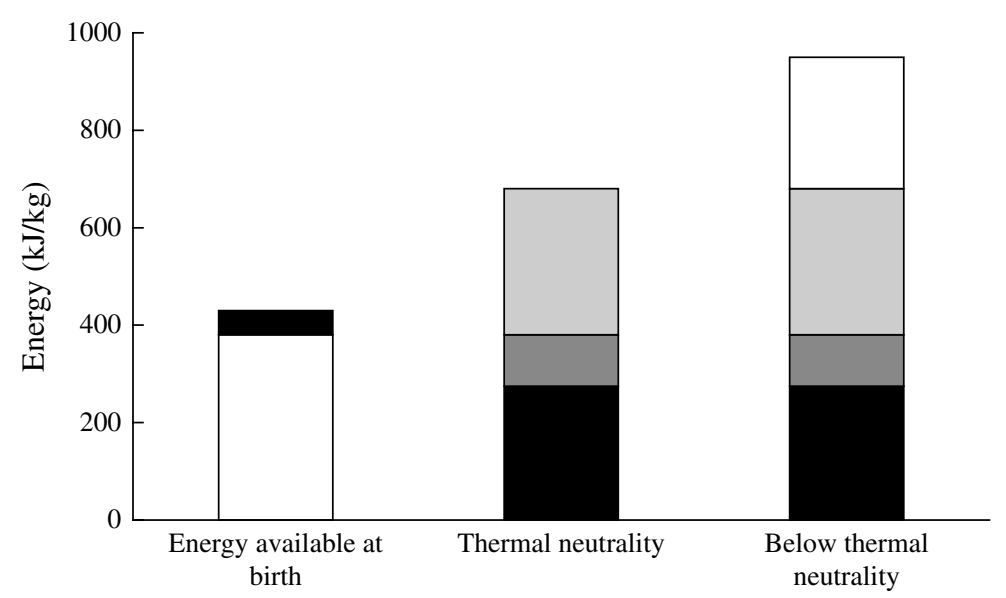

Fig. 1. Energy reserves available at birth ( $\square$, fat; $\square$, glycogen) and estimated net energy requirements during the first $24 \mathrm{~h}$ of life of piglets surviving to weaning in conditions of thermal neutrality or $5{ }^{\circ} \mathrm{C}$ below thermal neutrality $(\boldsymbol{\square}$, maintenance; $\square$, physical activity; $\square$, energy retention; $\square$, thermoregulation); from Mellor \& Cockburn 1986; J. Le Dividich (unpublished).

physical activity during the first day of life emphasizing the importance of colostrum as a provider of energy.

\section{COLOSTRUM : PRODUCTION BY THE SOW AND CONSUMPTION BY THE PIGLET}

Colostrum is the first secretion of the mammary gland. Its production is continuous during parturition (Hemsworth et al. 1976) and then becomes discontinuous, with nursing occurring at regular intervals of 40-60 min. Early nutrition is of vital importance for the piglet, which usually starts to suck within 20-30 min of birth. The amount of colostrum consumed by the piglet is dependent on the ability of the sow to produce colostrum and that of the piglet to reach and extract colostrum from the udder.

\section{Colostrum production by the sow}

Colostrum production by the sow is usually estimated from increases in litter weight between birth and $24 \mathrm{~h}$ old (Devillers et al. 2004). Colostrum intake by piglets accounts for $0.86-0.88$ of the variation in individual piglet body weight gain (Le Dividich et al. 2005), indicating that litter weight gain during the first $24 \mathrm{~h}$ after birth is a good marker of the amount of colostrum consumed by the piglet and hence produced by the sow. The main characteristic of colostrum production is its very high variability. In a study involving 47 sows, mean litter weight gain during the first $24 \mathrm{~h}$ after birth was $1007 \mathrm{~g}$ with a CV of $75 \%$ (Le Dividich et al. 2004). Thompson \& Fraser (1988) also observed large differences in weight gain between litters during the first few days after farrowing, suggesting there were large differences between sows in the early availability of milk. A similar variability has been reported in ewes (Pattinson et al. 1995; Pattinson \& Thomas 2004). Litter weight gain and therefore colostrum production by the sow is largely independent of litter characteristics such as litter size (Fig. 2) and the sow herself accounts for 0.65 of variability in litter weight gain and colostrum production. Several sow-related factors, including health, premature farrowing, changes in reproductive hormones and metabolism, parity, nutrition and genetics, can theoretically be involved in this wide variation in colostrum production.

Either failure to produce or a low yield of colostrum might be caused by the occurrence of Metritis, Mastitis and Agalactia syndrome, a common disorder in peripartal sows. However, in the above study (Le Dividich et al. 2004), this syndrome was only detected in one sow. In ewes, there is a close relationship between the level of feeding during pregnancy and the amount of colostrum produced (Mellor \& Murray 1985). Feed restriction (0.80 of ad libitum) during prepuberty impairs mammogenesis of gilts slaughtered after their first or second oestrus (Farmer et al. 2004). However, whether the level of feeding during pregnancy has effects on the development of the udder at farrowing, and on colostrum production, is not known. Premature farrowing (110-111 days) reduces colostrum production by $40 \%$ (Milon et al. 1983). In practice, however, less than 0.02 of sows farrow before 112 days (Aumaître et al. 1979; L. Canario, personal communication). Marked changes in reproductive hormones occur in the periparturient sow, these being mainly a withdrawal of progesterone and an increase in prolactin, estradiol$17 \beta$ and corticosteroids. Poor milk production has 


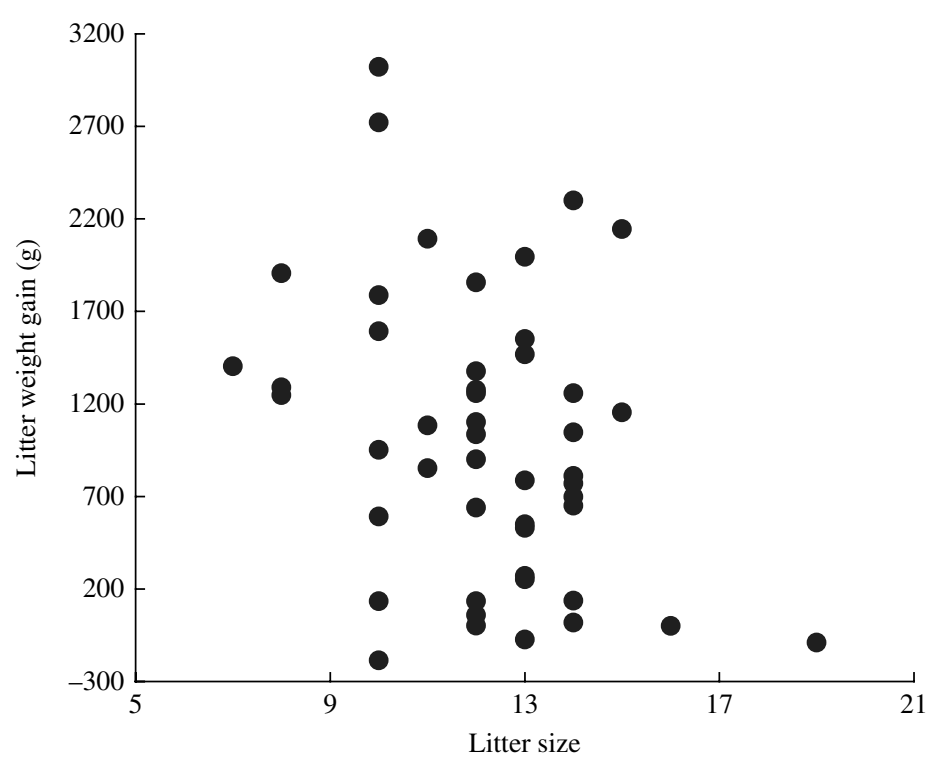

Fig. 2. Total litter weight gains (g) from birth to $24 \mathrm{~h}$ of age in relation to litter size (from Le Dividich et al. 2004).

been associated with an early withdrawal of progesterone, whereas high concentrations of the hormone post-farrowing have been associated with delayed lactogenesis and poor initial (birth-3 days) litter weight gain (de Passillé et al. 1993). The metabolism of the periparturient sow changes gradually from an anabolic to a catabolic state. From this viewpoint, the colostral phase is characterized by a large export of protein. On the basis that the ratio of colostrum consumption to piglet weight gain is 2.4 (the present authors' unpublished data) and the mean concentration of protein in colostrum is $100 \mathrm{mg} / \mathrm{g}$ (Klobasa et al. 1987), total export of protein through colostrum during the first $24 \mathrm{~h}$ ranges from $260-600 \mathrm{~g}$. Due to the habitual low feed intake of the sow soon after parturition, this export probably results in a high rate of the sow body protein catabolism even though most colostral immunoglobulins originate from sow plasma. These comments suggest that changes in reproductive hormones and metabolism must be closely synchronized with parturition. Finally, milktype ewes are reported to produce significantly more colostrum than meat-type ewes (Pattinson \& Thomas 2004), suggesting that the ability to produce colostrum has some genetic component. Again, it is not known whether the ability of the sow to produce colostrum has a genetic component.

\section{Colostrum consumption by the piglet}

The initial rate of intake is very rapid, representing up to $0.07 \mathrm{BW}$ in the first two postnatal hours (Fraser \& Rushen 1992), and gradually decreases thereafter.
When an unrestricted supply of colostrum is available, consumption amounts to 450 (s.E. 38) g/ $/ \mathrm{kg} \mathrm{BW}$ (Le Dividich et al. 1997), suggesting that the ingestive capacity of the pig is very high at birth and could compensate for its limited energy reserves. In sowreared piglets, colostrum consumption over the first $24 \mathrm{~h}$ after birth, predicted from piglet weight gain (Devillers et al. 2005) or determined from weighsuckle-weigh measurements (Le Dividich \& Noblet 1981; Milon et al. 1983; Bland et al. 2003), ranges from $210-280 \mathrm{~g} / \mathrm{kg}$ BW. However, the within-litter $\mathrm{CV}$ of colostrum consumption ranges from $15-110 \%$ (mean $40 \%$ ), while between-litter CV averages $30 \%$, indicating that colostrum consumption is highly variable. Within-litter the main factors influencing colostrum consumption may include birth weight, birth order and litter size. Heavier piglets at birth are more competitive at the udder and more able to extract colostrum from the teats than their lighter littermates. Thus, colostrum consumption increases by $26-37 \mathrm{~g}$ per $100 \mathrm{~g}$ increase in BW (Le Dividich et al. 2004; Devillers et al. 2005). In the study of Devillers et al. (2005), 0.45 of sows produced more than $3100 \mathrm{~g}$ of colostrum. On the basis that the ingestion of $160-170 \mathrm{~g}$ colostrum/ $\mathrm{kg}$ BW is required to ensure survival (see later in the present paper) and the average BW of a piglet is $1400 \mathrm{~g}$, then $0 \cdot 45$ of sows produce enough colostrum to feed a litter of 12-13 piglets adequately provided that colostrum is equally distributed among the piglets (J. Le Dividich, F. Thomas \& G. P. Martineau, personal communication), thus illustrating the importance of the litter homogeneity. Furthermore, the time interval between 


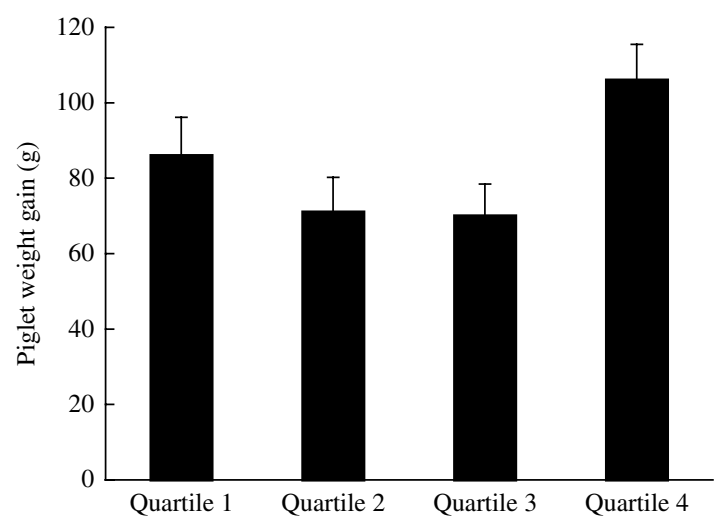

Fig. 3. Effect of birth order on mean weight gain (with S.E.) of piglets from birth to $24 \mathrm{~h}$ of age (duration of farrowing was divided into quartiles).

birth and the first suckling is greater in lighter piglets (Le Dividich et al. 1998). Birth order has no effect on BW gain (Fig. 3) during the first $24 \mathrm{~h}$ after birth (Castrén et al. 1991; Devillers et al. 2005) probably because, since the rate of colostrum consumption is highest during the first few hours after birth (Castrén et al. 1991; Fraser \& Rushen 1992), the first-born piglets are sated and therefore less active when later piglets are born. The ensuing reduced competition for teats would allow later-born piglets to display more teat-seeking activity, explaining why birth order has no effect on BW gain. As colostrum production by the sow is independent of litter size, then colostrum available per piglet decreases by $22-42 \mathrm{~g}$ per each additional piglet born (Le Dividich et al. 2004; Devillers et al. 2005) (Fig. 4). Other factors including cold exposure (Le Dividich \& Noblet 1981) and splayed limbs at birth (Devillers et al. 2005) markedly decrease colostrum consumption, while birth hypoxia results in both an increase in the interval between birth and first suckling and a decrease in colostrum consumption (Herpin et al. 1996).

\section{Nutritional value of colostrum}

\section{Gross composition}

The composition of colostrum and milk, including amino acids, vitamins and minerals, has been the subject of several reviews (Hartman \& Holmes 1989; Rooke \& Bland 2002) and will not be detailed here. In brief, the composition of colostrum is characterized by rapid changes to that of milk in the course of 24-30 h after birth. Compared with milk, colostrum has higher concentrations of dry matter and crude protein and lower concentrations of fat and lactose (Fig. 5). However, a major characteristic is the wide variation in protein concentration associated with the variation in immunoglobulin concentration (see later). Fats are the main source of energy, accounting for 0.40 to 0.60 of the total energy supplied by colostrum. Colostrum and milk fats are composed of long chain fatty acids $(\geqslant 14 \mathrm{C})$. The content and the composition of fat are both largely dependent on the fat composition of the diet fed to the sow during late pregnancy, which allows manipulation of the diet of the sow to provide colostrum fatty acids (C18:1, C18:2; Schmidt \& Herpin 1998) that are oxidized at the highest rate by the piglet. In contrast to fat, colostrum and milk lactose are only marginally related to the diet of the sow, while colostrum amino acid composition $(\mathrm{g} / 16 \mathrm{~g} \mathrm{~N})$ is remarkably constant. However, colostrum contains more threonine than milk because of the high content of this amino acid in immunoglobulins.

Compared with milk, colostrum contains fewer minerals, with a lower concentration of the major elements $(\mathrm{Ca}, \mathrm{P})$, but higher concentrations of trace elements ( $\mathrm{Zn}, \mathrm{Fe})$. Finally, sow colostrum and milk contain a variety of growth factors and hormones (Table 1; for details, see the review of Xu et al. 2002), including insulin-like growth factors (IGF) 1 and 2, insulin, epidermal growth factor (EGF), transforming growth factor-beta (TGF $\beta$ ) and leptin (Estienne et al. 2000). In general, the concentration of growth factors in colostrum falls over the first day of life and therefore any positive effects of growth factors may be diminished in later-born piglets. The amounts of these factors in colostrum and their impact on the acceleration of intestinal tissue growth and maturation of the gut resulting from colostrum ingestion have recently been reviewed (Xu et al. 2002). Colostrum also contains protease inhibitors which are present in greater concentrations in colostrum than in milk (Zhou et al. 2003).

\section{Digestion and utilization of colostral energy and nitrogen}

New-born pigs have low energy stores and it is essential that the intestine be functional at birth. In fact, its digestive tract is primed for postnatal life. Correspondingly, late fetal life is characterized by a marked decline in stomach $\mathrm{pH}$. The activity of chymosin, the major milk-clotting protease of the gastric mucosa, is maximal at birth (Sangild et al. 2000). Most pancreatic and intestinal brush-border enzymes are present at birth but levels of expression vary. Pancreatic enzymes generally show low activity. The low activity of lipase is intriguing, considering that fats are the main source of energy of colostrum. However, this low activity is compensated for by the appreciable amount of lipase in sow milk (Chandan et al. 1968) while specific and total activities of intestinal fatty acid binding protein are markedly stimulated by colostrum ingestion (Reinhart et al. 1992). 


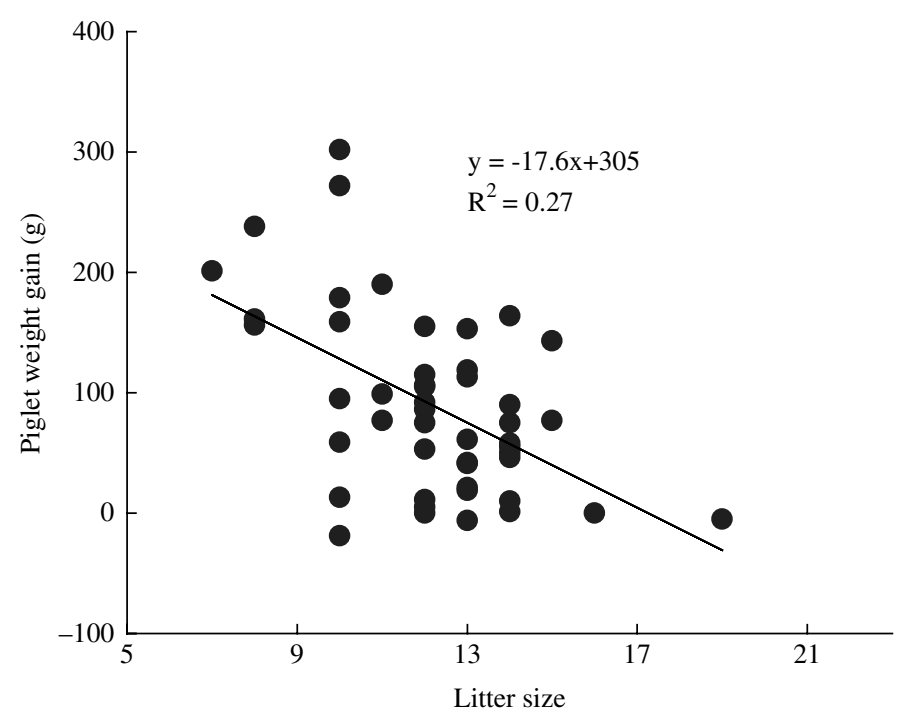

Fig. 4. Average piglet weight gain (g) from birth to $24 \mathrm{~h}$ of age in relation to litter size. (From Le Dividich et al. 2004.)

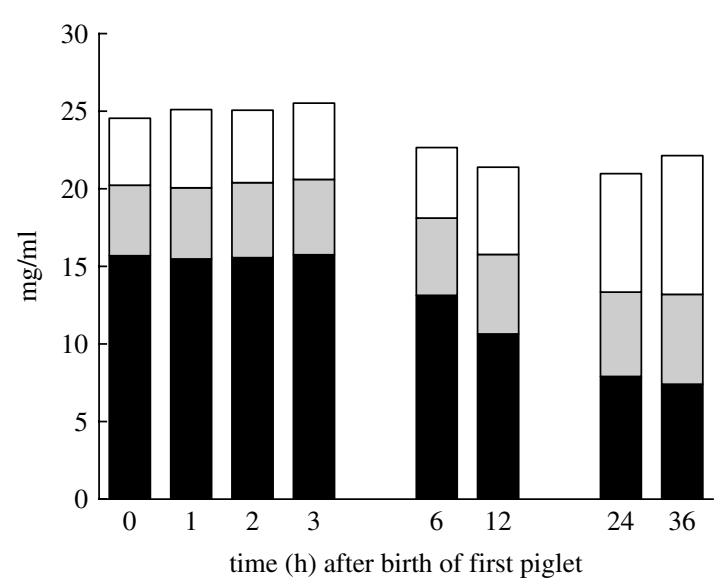

Fig. 5. Changes in the composition ( $\square$, lipid; $\square$, lactose; $\mathbf{\square}$, crude protein) of colostrum from birth of the first piglet in the litter to $36 \mathrm{~h}$ thereafter (J. Le Dividich, F. Thomas, \& G. P. Martineau, personal communication).

The proteolytic activity of the digestive tract is low at birth, thus assisting the absorption of intact immunoglobulins. However, high activities of two major lysosomal proteinases, cathepsins $\mathrm{B}$ and $\mathrm{D}$ (Ekström \& Weström 1991), are found in the intestinal mucosa, suggesting that some intracellular degradation of internalized protein (immunoglobulins) does occur in the enterocyte. Among the intestinal enzymes, the main characteristic of the newborn piglet is the high lactase expression compared with sucrase. Rates of intestinal transport of the constituent monosaccharides of lactose, glucose and galactose, are highest at birth (Puchal \& Buddington 1992) and ingestion of colostrum results in a rapid increase in plasma glucose (Le Dividich \& Noblet 1984).

Colostrum and milk are utilized remarkably well by the piglet (Table 2), with both having ratios of $\mathrm{ME} / \mathrm{GE}$ of 0.93 and 0.98 , respectively, and a ratio of $\mathrm{N}$ retained/ $\mathrm{N}$ intake between 0.88 and 0.91 (Le Dividich et al. 1994; Noblet \& Etienne 1987; Marion \& Le Dividich 1999). True N digestibility of milk is lower (0.88) than apparent $\mathrm{N}$ digestibility, whilst amino acid true digestibility averages 0.92 (Mavromichalis et al. 2001). When expressed relative to lysine, the amino acid profile of colostrum and milk, with the exception of arginine, is close to that of the new-born piglet (Table 3). Arginine is markedly deficient in colostrum and milk (Wu et al. 1999) and it is not known whether endogenous synthesis is sufficient to meet arginine requirements of the neonatal pig. The efficiency of ME utilization for total energy retention and for energy retained as protein are higher for colostrum than for milk (0.91 v. $0.72 ; 0.90$ v. 0.56 , respectively (Le Dividich et al. 1994; Marion \& Le Dividich 1999). Compared with mature milk, colostrum specifically stimulates (1.5-fold) muscle protein synthesis (Burrin et al. 1992), with the synthesis being mostly restricted to the myofibril protein compartment (Fiorotto et al. 2000), probably contributing to muscle maturation since at birth the skeletal muscle contains very few myofibrils (Herpin et al. 2002).

Overall, the thermogenic importance of colostrum is illustrated by the direct linear relationship between heat production (and rectal temperature) and the 
Table 1. Concentrations of growth factors $(\mathrm{ng} / \mathrm{ml})$ in porcine colostrum and milk (from Xu et al. 2002)

\begin{tabular}{lccc}
\hline \hline & & \multicolumn{2}{c}{ Milk } \\
\cline { 3 - 4 } & Colostrum & \multicolumn{2}{c}{$\begin{array}{c}\text { Time of sample } \\
\text { (days post-partum) }\end{array}$} \\
\hline Epidermal growth factor & 1527 (s.E.M. 5·3) & 241 (s.E.M. 76) & 9 \\
Insulin & $12 \cdot 5$ (s.E.M. 3.3) & $1 \cdot 6$ (s.E.M. 0.5) & 9 \\
Insulin-like growth factor-1 & 136 (s.D. 23) & 72 (s.D. 11) & 1 \\
Insulin-like growth factor-2 & 291 (s.D. 64) & 165 (s.D. 18) & 1 \\
Transforming growth factor- $\beta$ & 190 (s.D. 56) & 73 & 0.5 \\
\hline \hline
\end{tabular}

Table 2. Utilization of sow colostrum and milk energy and nitrogen by the piglet (adapted from Le Dividich et al. 1994 and Marion \& Le Dividich 1999). Data are as coefficients

\begin{tabular}{lcc}
\hline \hline & Colostrum & Milk \\
\hline Apparent digestibility & & \\
$\quad$ Energy & 0.93 & 0.98 \\
$\quad$ Nitrogen & 0.95 & 0.99 \\
Metabolizable energy/gross energy & 0.93 & 0.98 \\
Efficiency of utilization of & & \\
metabolizable energy for & & \\
$\quad$ Energy retention & 0.91 & 0.72 \\
$\quad$ Energy retained as protein & 0.90 & 0.56 \\
\hline \hline
\end{tabular}

amount of colostrum consumed by the new-born pig during the first day postpartum, when kept at an environmental temperature of $18{ }^{\circ} \mathrm{C}$ (Noblet \& Le Dividich 1981).

\section{IMMUNOLOGICAL IMPORTANCE OF COLOSTRUM}

\section{Immune components of colostrum}

Colostrum contains a complex mix of constituents that directly or indirectly influence the immune competence of piglets. The most important constituents are the immunoglobulins that affect immune competence directly by providing passive immune protection both after absorption of intact immunoglobulin prior to 'gut closure' or at the gut mucosal level throughout lactation. Indirect effects may be mediated by influences on the immune system.

\section{Immunoglobulins}

Colostrum is characterized by a high concentration of immunoglobulin (Ig) $\mathrm{G}$ and lower concentrations of IgA and IgM (Curtis \& Bourne 1971; Klobasa et al. 1987) (Fig. 6). The concentration of IgG in colostrum is several-fold higher than in sow plasma
Table 3. Amino acid profile (expressed as $\mathrm{g} / 100 \mathrm{~g}$ lysine) of sow colostrum and milk compared with that of the new-born pig

\begin{tabular}{|c|c|c|c|c|}
\hline \multirow[b]{2}{*}{ Amino acids } & \multirow[b]{2}{*}{$\begin{array}{c}\text { New-born pig } \\
\text { Total }\end{array}$} & \multirow[b]{2}{*}{$\begin{array}{c}\text { Colostrum } \\
\text { Total }\end{array}$} & \multicolumn{2}{|r|}{ Milk } \\
\hline & & & Total & $\begin{array}{c}\text { True } \\
\text { digestible }\end{array}$ \\
\hline Lysine & 100 & 100 & 100 & 100 \\
\hline Arginine & 114 & 74 & 89 & 65 \\
\hline Histidine & 37 & 43 & 44 & 38 \\
\hline Isoleucine & 52 & 53 & 54 & 54 \\
\hline Leucine & 112 & 134 & 115 & 122 \\
\hline $\begin{array}{l}\text { Methonione }+ \\
\text { cysteine }\end{array}$ & 51 & 44 & 45 & 56 \\
\hline Threonine & 58 & 75 & 62 & 55 \\
\hline Tryptophan & 19 & 25 & 17 & 16 \\
\hline Valine & 77 & 81 & 72 & 73 \\
\hline
\end{tabular}

New-born pig, Wu et al. (1999); colostrum and milk total amino acids, King et al. (1999); milk true digestible amino acids, Mavromichalis et al. (2001).

and declines exponentially during the first $24 \mathrm{~h}$ of secretion. Thus, in mature milk, IgA rather than IgG is the dominant immunoglobulin. The initial concentration of $\mathrm{IgG}$ in colostrum varies widely even between sows on the same unit (Klobasa \& Butler 1987; Bland \& Rooke 1998; J. Le Dividich, F. Thomas \& G. P. Martineau, personal communication). Parity, season (Inoue et al. 1980) and genotype (Inoue et al. 1980; Klobasa et al. 1985) influence colostrum IgG concentrations. For example, first parity sows have lower colostrum IgG concentrations than multiparous sows (Inoue et al. 1980; Klobasa et al. 1986). There are also differences in colostrum IgG concentrations between different parts of the udder; caudal teats tended to have lower IgG concentrations than cranial teats in some studies (Bland \& Rooke 1998 ) but the reverse has also been reported (Klobasa \& Butler 1987). However, variation in colostrum immunoglobulin concentrations is dominated by 


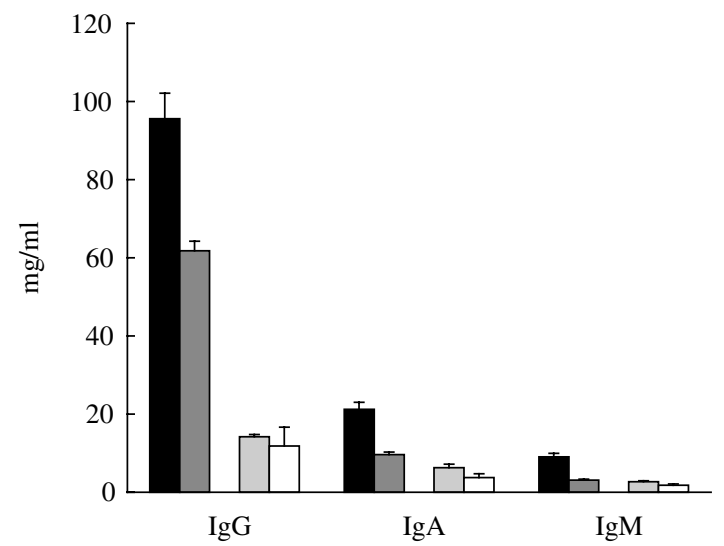

Fig. 6. Concentrations of immunoglobulins and colostrum (before suckling) and milk (24 h after birth). Data (means with S.E.) are adapted from Klobasa et al. (1981; colostrum 口, milk $\square$ ) and Curtis \& Bourne (1971; colostrum $\square$, milk $\square$ ).

sow-to-sow variation (Klobasa \& Butler 1987). It is therefore doubtful whether genetic selection has influenced colostrum immunoglobulin composition.

The transfer of IgG from sow plasma to colostrum is not well described. Bourne \& Curtis (1973) showed that essentially all $\mathrm{IgG}$ and $\mathrm{IgM}$ were derived from the serum of the sow. As in the cow, IgG uptake from serum is mediated by specific receptors on mammary epithelial cells (Huang et al. 1992). The $\mathrm{FcRn}$ (neonatal $\mathrm{Fc}$ receptor) receptor responsible has recently been characterized (Schnulle \& Hurley 2003) with FcRn mRNA expression decreasing on the day of farrowing. However, detailed information on the control of the FcRn receptor is not yet available to improve our understanding of variability in colostrum IgG concentrations.

\section{Cells and other constituents}

Colostrum contains leukocytes and other immunologically active cells. The leukocytes are absorbed from colostrum (Tuboly et al. 1988; Williams 1993) and migrate to mesenteric lymph nodes and other tissues of the piglet where they exert an immunomodulatory effect on responses to mitogens (Williams 1993). Bianchi et al. (1999) have attributed the relatively high frequency of $\operatorname{IgG}$ secreting cells in the spleen, lymph node and bone marrow of 1-week-old piglets to colostrum-derived cells. Colostrum also probably contains unidentified growth factors; for example, in bovine and human colostrum, a soluble CD14 protein has been detected which induces B cell growth and differentiation (Filipp et al. 2001).

The ability of an animal to mount an immune response is inter-linked with antioxidant status and therefore related to selenium (Arthur et al. 2003) and vitamin E (Pinelli-Saavedra 2003). The new-born piglet has lower tissue concentrations of Se and in particular vitamin $\mathrm{E}$ than the sow because of poor placental transport. Colostrum is a superior source of Se and vitamin E compared to milk (Mahan et al. 2000; Mahan \& Peters 2004) and vitamin E concentrations in piglet plasma therefore increase markedly in the $24 \mathrm{~h}$ following birth.

In summary, colostrum supplies a variety of immunologically active molecules and nutrients that support the immune response and it is a consistent characteristic of these constituents that firstly they are present in greater concentrations in colostrum than milk and secondly these concentrations decline sharply over the critical first $24 \mathrm{~h}$ of lactation.

\section{Can immune status of colostrum be changed?}

Surveys have suggested that vaccination of sows is associated with increased colostrum IgG concentrations (Inoue et al. 1980). However, when groups of sows on the same unit were vaccinated or not vaccinated, no changes in colostrum total $\mathrm{IgG}$ were noted (Arey et al. 2000). Titres of specific antibodies in colostrum, however, increase in response to effective vaccination of the sow. Non-specific immuno-stimulators have been reported to increase IgG concentrations (Krakowski et al. 2002) while prenatal stress decreases them (Tuchscherer et al. 2002).

Supplementing the diet of the sow with Se or vitamin $\mathrm{E}$ increases the concentrations in colostrum and milk and thus supply of these nutrients to the piglet (Mahan et al. 2000; Mahan \& Peters 2004). A more intriguing observation is that feeding sows a fermented liquid feed increased the mitogenic activity of colostrum when assayed against blood lymphocytes; no mechanism was given for this observation (Demecková et al. 2002)

\section{Transfer of maternal immunoglobulins to the new-born piglet}

\section{Immune status of the new-born}

Gaskins (1998) reviewed the development of active cellular immunity in the piglet and concluded that most aspects of the system were immature at birth. For example, T lymphocytes were present in the lamina propria of the intestine but in lower numbers than at 4 weeks old and with a higher proportion of the $\mathrm{CD} 2^{-} \mathrm{CD} 4^{-} \mathrm{CD} 8^{-}$subset. The ability of intestinal $\mathrm{T}$ cells to respond to mitogens was less well developed in the neonate and the numbers of antigen-presenting cells were lower. Similarly, blood mononuclear cells responded less well in the neonate to a T-cell dependent antigen and the numbers of immunoglobulin-secreting cells in spleen and bone 
marrow were lower at 1 than 4 weeks old. Thus, most components of the immune system of the piglet are present at birth but are functionally undeveloped and several weeks of life are necessary before the immune system becomes fully developed.

In part, underdevelopment of the piglet at birth is due to lack of exposure to antigens. Stimulation by either bacterial products or bacterially activated antigen presenting cells is necessary for B cells to differentiate to become antibody secreting cells (Butler et al. 2002a). The fetal pig is unusual in its ability to expand a repertoire of switched B-cells to a polyclonal repertoire without exposure to environmental antigen (Butler et al. 2002 b). Thus, fetuses can produce $\mathrm{IgG}$ and $\mathrm{IgM}$ in response to mitogen stimulation in utero (Tlaskalova-Hogenova et al. 1994) and spontaneously immunoglobulin-producing B cells have been isolated from fetal piglets (Cukrowska et al. 1996). The repertoire of B-cells may be the reason why immunoglobulins can be detected in the blood of new-born unsuckled piglets (Porter \& Hill 1970; Bianchi et al. 1992), albeit at up to a 1000-fold lower concentration than in suckling piglets. The source of IgG in fetal plasma may be not only de novo synthesis but also placental transmission, as the FcRn receptor has been detected in placental tissues (Butler et al. 2002b). Practically, however, the new-born piglet serum is largely lacking in serum IgG and since no increases in $\mathrm{IgG}$ concentration are detectable until at least 6 days after birth in colostrum-deprived piglets (Klobasa et al. 1981; Drew \& Owens 1988), maternal colostrum IgGs must provide $\mathrm{IgG}$ for passive immune protection until the piglet is able to synthesize adequate amounts of $\mathrm{IgG}$.

\section{Transfer of intact IgG from the gut to the circulation of the piglet}

Delivery of intact immunoglobulins to the small intestine where absorption of intact proteins takes place is facilitated by three factors. At birth and in the first days of life, the dominant protease in the stomach is chymosin rather than pepsin (Sangild et al. 2000), which results in the clotting of milk. Secondly, as mentioned above, the proteolytic activity of the gastro-intestinal tract is low at birth. Thirdly, colostrum contains protease inhibitors, which facilitate $\mathrm{IgG}$ absorption. Feeding of colostrum from which trypsin inhibitors had been removed (Carlsson et al. 1980) decreased transfer of IgG to the serum of the piglet, while this was increased by feeding colostrum with added trypsin inhibitors (Weström et al. 1985). Recently Zhou et al. (2003) confirmed the presence of both trypsin and chymotrypsin inhibitors in porcine colostrum and demonstrated that these inhibitors also protect growth factors in colostrum from hydrolysis.
The immunoglobulins in colostrum are rapidly taken up by non-specific pinocytosis into the enterocytes of the small intestine of the new-born piglet and localized in vacuoles (Payne \& Marsh 1962; Clarke \& Hardy 1971). The ability of fetal enterocytes to endocytose immunoglobulins is present before birth as demonstrated both in utero (Sangild et al. 1999) and in prematurely-born piglets (Sangild et al. 1997). However, enterocytes which develop postnatally lack the ability to endocytose intact proteins (Smith \& Jarvis 1978; Smith \& Peacock 1980). The complete replacement of the fetal population postnatally by these 'adult' enterocytes takes up to 19 days (Smith \& Jarvis 1978) and at 8 days old 0.38 of the cell population is still of the fetal type (Smith \& Peacock 1980). Cell replacement in the villus is therefore unable to explain the observed cessation of macromolecule transfer to the circulation of the piglet after 24-36 h of life. Cells are still able to take up macromolecules after cessation of transfer (Clarke \& Hardy 1971; Ekström \& Weström 1991) and the small intestine of the suckled piglet at 1 day old contains swollen epithelial cells with substantially increased protein contents (Burrin et al. 1992). Therefore, the critical event controlling the transfer of intact immunoglobulins to the circulation of the piglet is cessation of transfer across the basolateral membrane of the enterocyte. For this reason, gut closure is defined as cessation of transfer of $\operatorname{IgG}$ to the circulation of the piglet rather than cessation of $\operatorname{IgG}$ uptake into the enterocyte from the gut.

\section{Gut closure}

The interval between birth and gut closure is, therefore, the window for absorption of intact immunoglobulins. That closure takes place as early as $24 \mathrm{~h}$ old in suckling pigs was first noted by Speer et al. (1957) and has since been confirmed many times. Closure is, to a certain extent, developmentally programmed since fasting new-born piglets (Lecce \& Morgan 1962; Payne \& Marsh 1962) or feeding them intravenously (Mehrazar et al. 1993) delays but does not prevent closure. However, the presence of nutrients in the gut of the piglet and their absorption induces closure. Various studies with fractionated colostrum and pure nutrients (e.g. glucose) have shown that it is nutrients per se rather than the amount of IgG absorbed which induces closure (Lecce 1966, Werhahn et al. 1981).

Several hormones have been suggested as signals for closure. Svendsen et al. (1986) showed that administration of insulin to new-born piglets decreased transmission of marker proteins $12 \mathrm{~h}$ after birth. However, Burrin et al. (1995) concluded that colostrum-derived insulin made only a small contribution to the rise in serum insulin concentrations 
observed in colostrum-fed piglets. Therefore, the observed effect of insulin in reducing macromolecule absorption may be secondary to nutrient intake.

Increasing maternal cortisol by treatment with ACTH is associated with increased serum IgG concentrations in the new-born (Bate \& Hacker 1985). IgG concentrations at $48 \mathrm{~h}$ old are positively correlated with cortisol concentrations at birth (Sangild et al. 1997) and administration of metapyrone (an inhibitor of adrenal cortisol synthesis) reduces IgG concentrations at 3 days old (Patt \& Eberhardt 1976; Sangild et al. 1993). Thus, glucocorticoids have a stimulatory effect on IgG absorption. The pre-partum rise in cortisol concentrations may therefore be involved in development of the capacity to absorb macromolecules. This is relevant because (a) efficiency of $\mathrm{IgG}$ absorption is lower in utero (Sangild et al. 1999) than in new-born piglets and (b) premature piglets also have a reduced absorptive capacity for IgG (Sangild et al. 1997). In addition, inappropriate increases in cortisol concentration may induce premature maturation of the gut and reduce macromolecule absorption (Bate et al. 1991), emphasizing the importance of cortisol in developmental regulation of $\mathrm{IgG}$ absorption.

Many studies have observed the appearance in piglet blood of a range of dosed heterologous proteins and other macromolecules indicating a lack of selectivity of absorption. However, less attention has been paid to the naturally suckling piglet. Klobasa et al. (1981) demonstrated absorption of IgA, IgG and IgM by suckling piglets and variability between piglets in the extent of uptake of immunoglobulins. Carlsson et al. (1980) measured the appearance of IgG, albumin and $\beta$-lactoglobin in piglet serum and found that compared to colostrum, $\beta$-lactoglobin concentrations in piglet serum were lower than IgG and albumin. Using bovine colostrum-fed piglets, Kiriyama (1992) and Harada et al. (1999) showed selective protein transfer to serum and cerebrospinal fluid by electrophoretic characterization of proteins. Bland et al. (2003), using a similar approach, reported that IgG was selectively absorbed from porcine colostrum. The matrix in which $\operatorname{IgG}$ is presented to the piglet also influences absorption. Jensen et al. (2001) measured the uptake of porcine IgG and test proteins in piglets maintained on either porcine colostrum, porcine milk, porcine plasma or bovine colostrum. They found that absorption was greater from porcine and bovine colostrum than from milk or plasma, with porcine colostrum superior to bovine colostrum, and further suggested that bio-active factors in colostrum may enhance absorption.

Absorption of $\mathrm{IgG}$ by the gut of the new-born piglet is saturated by increasing amounts of colostrum or individual nutrients e.g. glucose or protein (Lecce et al. 1964; Pierce \& Smith 1967), probably because an individual enterocyte is only able to take up a finite amount of material. Recently, J. Le Dividich, F. Thomas \& G. P. Martineau, (personal communication) fed piglets different amounts of colostrum in hourly feeds over the first $27 \mathrm{~h}$ of life. Colostrum composition was changed throughout the experiment to reflect natural changes in the first day of life. Plasma IgG concentrations reached a plateau in the first $20 \mathrm{~h}$ of suckling and as colostrum intake increased, the absorption of a test protein (at $24 \mathrm{~h}$ old) decreased from 0.27 to 0.04 of that measured at birth. The key observation was that while the lowest colostrum intake $(70 \mathrm{~g} / \mathrm{kg} \mathrm{BW} / 24 \mathrm{~h})$ was insufficient to maintain piglet body weight, gut closure was well advanced, if not complete, at $24 \mathrm{~h}$ old; conversely, at intakes of $280 \mathrm{~g} / \mathrm{kg} \mathrm{BW} / 24 \mathrm{~h}$ and above, which the majority of sow-suckled piglets achieve (Bland et al. 2003; Devillers et al. 2005), gut closure was essentially complete after $24 \mathrm{~h}$ and IgG absorption did not differ between treatments.

In summary, absorption and transmission of $\mathrm{IgG}$ to the circulation of the piglet takes place when the gastro-intestinal tract of the piglet is predisposed to absorption of intact macromolecules. Available evidence shows that uptake of $\mathrm{IgG}$ is to some extent selective and facilitated by other constituents of porcine colostrum. Colostrum intake specifically stimulates the functional maturation of the gastrointestinal tract (see review by Xu et al. 2002) in the first $24 \mathrm{~h}$ of life and is the main factor that induces gut closure. Functionally, this process ensures that if the suckling piglet has an adequate colostrum intake, sufficient IgG should be absorbed in a minimum time thus reducing the chances of invasion by pathogens prior to gut closure.

\section{Factors affecting acquisition of $\operatorname{Ig} G$ by suckling piglet}

There may be a need in some circumstances to increase the amount of $\mathrm{IgG}$ absorbed by the piglet, particularly where the colostrum IgG supply is limited. The position of the piglet in the birth order is one of the main factors cited, with piglets late in the birth order having access to colostrum of lower IgG concentration and reduced plasma $\operatorname{IgG}$ concentrations (de Passillé et al. 1988; Bland et al. 2003; Klobasa et al. 2004; J. Le Dividich, F. Thomas \& G. P. Martineau, personal communication). However, reduced IgG concentrations do not always lead to an increased risk of mortality (de Passillé et al. 1988; J. Le Dividich, F. Thomas \& G. P. Martineau, personal communication). Explanations for this may be differences in the health status of the piggery and a failure to differentiate between piglets who had obtained an adequate intake of colostrum, albeit of reduced IgG concentration (Bland et al. 2003; J. Le Dividich, F. Thomas \& G. P. Martineau, personal communication) and those whose colostrum intake 
was sub-optimal. Since those factors that influence the ability of the piglet to consume adequate quantities of colostrum for growth and maintenance are equally relevant for IgG intake and absorption, only factors that specifically influence IgG absorption will be discussed. Two main opportunities are available to improve IgG absorption.

\section{To increase colostrum IgG concentrations}

As discussed earlier, the wide variation in colostrum IgG concentrations between sows is poorly understood and there is a scarcity of data on its heritability and indeed whether IgG concentration is consistent between lactations in the same sow. Thus, the potential for improvement in this area is currently limited.

\section{To delay intestinal closure and/or increase efficiency of IgG absorption before gut closure}

As noted above, closure appears to be genetically programmed and in practice is stimulated by intakes of colostrum insufficient to maintain body weight. Therefore, there is little scope for delaying closure, which may in any case be inadvisable because of the risks of disease transmission. In most cases, where increased IgG uptake has been reported, differentiation between increased absorption and delayed closure as mechanisms is not possible. There have been reports of hormonal factors influencing closure in addition to the effects of insulin and corticosteroids mentioned earlier; treatment of piglets with oestradiol (Bate \& Hacker 1982) reduced birth to suckling interval which may increase $\mathrm{IgG}$ intakes by increasing intakes of early high $\mathrm{IgG}$ concentration-containing colostrum.

Increasing the vitamin $\mathrm{A}$ and $\mathrm{E}$ content of the diet of the sow has been shown to influence the $\operatorname{IgG}$ status of the piglet in several studies (reviewed by Rooke \& Bland 2002). The mechanisms by which antioxidant vitamins increased efficiency of $\mathrm{IgG}$ absorption are unclear and warrant further investigation. However, caution must be taken against oversupplementation of the maternal diet. For example, in pregnant ewes excess consumption of mineral blocks has resulted in depressed absorption of $\mathrm{IgG}$ by suckling lambs (Boland et al. 2004).

In terms of environment, cold stress of the sow in the last 10 days before parturition may increase $\operatorname{IgG}$ absorption by the piglet, presumably by increasing maternal cortisol concentrations (Bate \& Hacker 1985). However, cold stress of the piglet itself reduces plasma IgG concentrations, presumably by reducing colostrum intakes (Blecha \& Kelley 1981; Le Dividich \& Noblet 1981; Kelley et al. 1982; Milon et al. 1983).

\section{Development of active immunity}

Klobasa et al. (1981) modified the amounts of colostrum IgG absorbed by piglets by delaying suckling for varying times and found that the appearance of IgG synthesized by the piglet was progressively delayed as the amount of IgG absorbed from colostrum increased. Thus, there was a negative relationship between development of active immunity and the acquisition of passive immunity, with serum IgG concentrations not reaching a minimum until 5 weeks old. However, a weakness of observations based on serum or plasma concentrations is that no account is taken of the growth of the piglet and consequent expansion of plasma volume. Recent observations (Rooke et al. 2003) suggested that in normally suckling piglets there was no evidence for appearance of $\operatorname{IgG}$ synthesized by the piglet before 7 days old but by 14 and 21 days old, 0.33 and 0.44 respectively of plasma $\mathrm{IgG}$ was not of maternal origin. Thus, synthesis of $\operatorname{IgG}$ by the normally suckling piglet begins much earlier than previously realized. Indeed, piglets deprived of colostrum and therefore maternal IgG (Klobasa et al. 1981; Drew \& Owens 1988) begin to synthesize $\operatorname{IgG}$ from 7 days old. In addition, when concentrations of plasma IgG at 7 and 28 days old were compared a positive curvilinear relationship was found between IgG at 7 and 28 days old, implying that the amount of IgG at 28 days old, which includes newly synthesized $\mathrm{IgG}$, was positively related to maternal IgG present at 7 days old. Similar relationships between plasma IgG concentrations at $48 \mathrm{~h}$ and weaning at 26 days old have been found by Le Dividich et al. (2005) and between antibodies to porcine parvovirus at 7 and 28 days old (Damm et al. 2002).

\section{Colostrum replacement}

In situations where it is necessary to provide nutrition to piglets other than by suckling the sow, what are the implications for $\operatorname{IgG}$ absorption and passive immune protection? Raising piglets entirely on milk replacers without any supplementary IgGs requires clean environmental conditions with little or no pathogen challenge (Varley et al. 1985; Drew \& Owens 1988). Even in those conditions mortality is high both pre- and post-weaning (Varley et al. 1986). Success is improved when either purified immunoglobulins (bovine or ovine) or immunoglobulins in the form of plasma, milk or colostrum are fed. There is, however, a clear advantage of porcine IgGs over bovine IgGs (Drew \& Owens 1988; Gomez et al. 1998) both in survival and in absorption of IgGs. The recent work of Jensen et al. (2001) provides an interpretation for this, since absorption of protein is facilitated in colostrum in preference to milk or plasma and by porcine rather than bovine colostrum. Therefore, for immune protection a replacer feed containing some proportion of porcine colostrum would be preferred and addition of purified porcine $\mathrm{IgG}$ would enhance the amounts of IgG absorbed. 
Table 4. Birth weight $(B W, g)$ and weight gain in first 24 h of life $(\mathrm{g} / \mathrm{kg} \mathrm{BW})$ of piglets dying after birth according to J. Le Dividich, F. Thomas \& G. P. Martineau (personal communication)

\begin{tabular}{|c|c|c|c|c|}
\hline \multirow[b]{2}{*}{ Range } & \multicolumn{4}{|c|}{ Birth weight class } \\
\hline & $\begin{array}{c}\text { Less than } \\
\text { (Mean - S.D.) }\end{array}$ & $\begin{array}{c}\text { (Mean - S.D. }) \text { to } \\
\text { Mean }\end{array}$ & $\begin{array}{c}\text { Mean to } \\
(\text { Mean+S.D. })\end{array}$ & $\begin{array}{l}\text { Greater than } \\
(\text { Mean + S.D.) }\end{array}$ \\
\hline \multicolumn{5}{|l|}{ All piglets } \\
\hline Number & 30 & 62 & 76 & 30 \\
\hline BW & $908 \pm 253$ & $1218 \pm 240$ & $1558 \pm 217$ & $1764 \pm 254$ \\
\hline Gain to $24 \mathrm{~h}$ & $-54 \pm 119$ & $48 \pm 75$ & $62 \pm 65$ & $67 \pm 44$ \\
\hline \multicolumn{5}{|l|}{ Surviving piglets } \\
\hline Number & 10 & 52 & 65 & 30 \\
\hline BW & $1096 \pm 170$ & $1222 \pm 246$ & $1567 \pm 217$ & $1764 \pm 254$ \\
\hline Gain to $24 \mathrm{~h}$ & $68 \pm 103$ & $66 \pm 67$ & $69 \pm 62$ & $67 \pm 44$ \\
\hline \multicolumn{5}{|l|}{ Piglets dying after birth } \\
\hline Number & 20 & 10 & 11 & None \\
\hline BW & $814 \pm 237$ & $1198 \pm 215$ & $1499 \pm 222$ & \\
\hline Gain to $24 \mathrm{~h}$ & $-115 \pm 69$ & $-43 \pm 48$ & $6 \pm 51$ & \\
\hline Gain to death & $-99 \pm 64$ & $117 \pm 294$ & $21 \pm 215$ & \\
\hline Age at death (days) & $1 \cdot 5 \pm 0 \cdot 7$ & $4 \cdot 3 \pm 2 \cdot 3$ & $6 \cdot \overline{9 \pm} 5 \cdot 2$ & \\
\hline
\end{tabular}

Only litters (15) where there was at least one death were included in the analysis.

\section{INSUFFICIENT ENERGY AND (OR) IMMUNOGLOBULINS INTAKE AS MAJOR CAUSES OF PRE-WEANING MORTALITY?}

In major pig-producing countries, pre-weaning losses of live-born piglets range between $10-13 \%$ and more if stillbirths are correctly diagnosed (Edwards 2002). These losses have a serious economic impact and are unacceptable from an animal welfare point of view. Many surveys have been carried out to examine causes of death (see review in Edwards 2002). However, while major terminal causes (including overlying by the sow) are well-known, underlying mechanisms are less well understood. These mechanisms may depend at what age pre-weaning losses occur. Most losses occur in the first $48 \mathrm{~h}$ after birth. There is increasing evidence that failure to achieve a regular and adequate intake of colostrum (energy) is likely to be both a direct and an underlying cause of the majority of deaths (Dyck \& Swiestra 1987; de Passillé \& Rushen 1989; Weary et al. 1996, Tuschscherer et al. 2000; Edwards 2002). A recent report by J. Le Dividich, F. Thomas \& G. P. Martineau (personal communication) indicated that, with the exception of some piglets where overlying was the primary cause of death, piglets dying after birth gained several times less weight (and hence had consumed less colostrum and energy) during the first $24 \mathrm{~h}$ after birth than survivors (Table 4). Similarly, Devillers et al. (2005) found that piglets dying during the first 5 days after birth had consumed much less colostrum $(70 v .330 \mathrm{~g})$ than survivors. Therefore, piglets consuming less colostrum would be less vigorous and less able to compete for productive teats, and hence they are more prone to die by hypothermia and (or) undernutrition. According to Devillers et al. (2005) and J. Le Dividich, F. Thomas \& G. P. Martineau (personal communication), colostrum intake required for survival to weaning is in the range of $160-170 \mathrm{~g} / \mathrm{kg}$ BW. The acquisition of insufficient passive immunity is unlikely to be a major factor underlying these early production losses. Hendrix et al. (1978), Blecha \& Kelley (1981) and Klobasa et al. (1981) reported that low IgG concentrations in blood serum soon after birth are associated with subsequent mortality and morbidity, but these observations may simply reflect an inadequate energy intake. Also, as mentioned previously in the present report, piglets born later have less immune protection, but are not at a higher risk of dying. From this it is tempting to speculate that the acquisition of a high level of passive immunity is not a determinant of survival. However, inadequate transfer of maternal antibodies to the new-born piglet may increase susceptibility to infections in the latter part of lactation and after weaning (Varley et al. 1986), while low humoral immunity at weaning influences post-weaning performance (Edwards \& Rooke 1999). Therefore, because of the positive relationship between development of active immunity and the acquisition of passive immunity (see above) a high level of passive immunization is desirable.

In summary, an early and high intake of colostrum (energy) is a major determinant of survival during the early suckling period when most losses 
occur. However, the acquisition of a high level of passive immunity is desirable as it may influence directly the development of active immunity and indirectly the health and performance of the weaned pig.

\section{CONCLUDING REMARKS}

The present paper has discussed a number of aspects of nutritional and immunological roles of colostrum for the neonatal piglet but has by no means covered all aspects of this exciting and important field of interest. Overall, colostrum (energy) intake is the major determinant of early survival. However, factors initiating and controlling colostrum production of the sow, and the delayed effects on passive immunization of the health and growth of the piglet warrant future research. Further, breeding companies have been successful in developing more prolific genotypes. However, to what extent the ability of the sow to produce colostrum has been increased proportionally is not known. Finally, providing an equal opportunity for each littermate to survive and thrive can be defined as the main quality of the sow. On this basis, the ability of the sow to produce colostrum, her nursing behaviour and the ability of each piglet to acquire sufficient colostrum are important factors. The homogeneity of piglet birthweight within a litter has a genetic component (Knol et al. 2002). Whether the ability of the sow to produce colostrum has also a genetic component is not known. Selection of the sow on her overall maternal quality and hence on her ability to produce colostrum offers a new and exciting field of research.

\section{REFERENCES}

Arey, D. S., Sinclair, A., Edwards, S. A. \& Rooke, J. A. (2000). Effects of re-grouping on behaviour, immune function and production in sows. Proceedings of the British Society of Animal Science, 2000, p. 136.

Arthur, J. R., Mckenzie, R. C. \& Beckett, G. J. (2003). Selenium in the immune system. Journal of Nutrition 133, 1457S-1459S.

Aumaître, A., Deglaire, B. \& Lebost, J. (1979). Premature farrowing in the sow and significance of piglet birth weight. Annales de Biologie Animale, Biochimie, Biophysique 19, 267-275.

Bate, L. A. \& Hacker, R. R. (1982). Estrogens and piglet viability. II. Effect of estrogen on piglet viability. Journal of Animal Science 54, 1017-1022.

Bate, L. A. \& Hacker, R. R. (1985). The influence of the sow's adrenal activity on the ability of the piglet to absorb $\mathrm{IgG}$ from colostrum. Canadian Journal of Animal Science 65, 77-85.

Bate, L. A., Ireland, W., Connell, B. J. \& Grimmett, B. (1991). Development of the small intestine of piglets in response to prenatal elevation of glucocorticoids. Histology and Histopathology 6, 207-216.

Bianchi, A. T. J., Zwart, R. J., Jeurissen, S. H. M. \& Moonen-Leusen, B. H. W. M. (1992). Development of the B- and T-cell compartments in porcine lymphoid organs from birth to adult life: an immunohistochemical approach. Veterinary Immunology and Immunopathology 33, 201-221.

Bianchi, A. T. J., Scholten, J.-W., Moonen-Leusen, B. H. W. M. \& Boersma, W. J. A. (1999). Development of the natural response of immunoglobulin secreting cells in the pig as a function of organ, age and housing. Developmental and Comparative Immunology 23, 511520.

Bland, I. M. \& Rooke, J. A. (1998). Effects of sow, udder section and time on colostrum immunoglobulin $G$ (IgG) concentrations and piglet colostrum intake. In Proceedings of the British Society of Animal Science, 1998, p. 158.

Bland, I. M., Rooke, J. A., Bland, V. C., Sinclair, A. G. \& Edwards, S. A. (2003). Appearance of immunoglobulin G in the plasma of piglets following intake of colostrum, with or without a delay in sucking. Animal Science 77, 277-286.

Blecha, F. \& Kelley, K. W. (1981). Cold stress reduces the acquisition of colostral immunoglobulin in piglets. Journal of Animal Science 52, 594-600.

Boland, T. M., Brophy, P. O., Callan, J. J., Quinn, P. J., Nowakowski, P. \& Crosby, T. F. (2004). The effects of mineral-block components when offered to ewes in late pregnancy on colostrum yield and immunoglobulin $G$ absorption in their lambs. Animal Science 79, 293-302.

Bourne, F. J. \& Curtis, J. (1973) The transfer of immunoglobulins IgG, IgA and IgM from serum to colostrum and milk in the sow. Immunology 24, 157-162.

Burrin, D. G., Schulman, R. J., Reeds, P. J., Davis, T. A. \& Gravitt, K. R. (1992). Porcine colostrum and milk stimulate visceral organ and skeletal muscle protein synthesis in neonatal piglets. Journal of Nutrition 122, 1205-1213.

Burrin, D. G., Davis, T. A., Ebner, S., Schoknecht, P. A., Fiorotto, M. L., Reeds, P. J. \& Mcavoy, S. (1995). Nutrient-independent and nutrient-dependent factors stimulate protein synthesis in colostrum-fed newborn pigs. Pediatric Research 37, 593-599.

Butler, J. E., Sun, J., Weber, P., Ford, S. P., Rehakova, Z., Sinkora, J., Francis, D. \& Lager, K. (2002a). Switch recombination in fetal porcine thymus is uncoupled from somatic mutation. Veterinary Immunology and Immunopathology 87, 307-319.

Butler, J. E., Weber, P., Sinkora, M., Baker, D., Schoenherr, A., Mayer, B. \& Francis, D. (2002b). Antibody repertoire development in fetal and neonatal piglets. VIII. Colonization is required for newborn piglets to make serum antibodies to T-dependent and type 2 T-independent antigens. Journal of Immunology 169, 6822-6830.

Canario, L., Tribout, T., Thomas, F., David, C., Cogué, J., Herpin, P., Bidanel, J. P., Père, M. C. \& Le Dividich, J. (2005). Estimation of the effects of selection using frozen semen, between 1977 and 1998 in Large White population, on body composition and physiological state of 
the new-born piglet. Journées de Recherches Porcine en France 37, in press.

Carlsson, L. C. T., Weström, B. R. \& Karlsson, B. W. (1980). Intestinal absorption of proteins by the neonatal piglet fed on sow's colostrum with either natural or experimentally eliminated trypsin-inhibiting activity. Biology of the Neonate 38, 309-320.

Castrén, H., Algers, B. \& SAloniemi, H. (1991). Weightgain pattern in piglets during the 1st 24 -h after farrowing. Livestock Production Science 28, 321-330.

Chandan, R. C., Parry, R. M. \& Shahani, K. M. (1968). Lyzozyme, lipase and ribonuclease in milk of various species. Journal of Dairy Science 51, 606-607.

Clarke, R. M. \& HARdy, R. N. (1971). Histological changes in the small intestine of the young pig and their relation to macromolecular uptake. Journal of Anatomy 108, 63-77.

Cranwell, P. D. (1995). Development of the neonatal gut and enzyme systems. In The Neonatal Pig. Development and Survival (Ed. M. Varley) pp. 99-154. Wallingford, UK: CAB International.

Cukrowska, B., Sinkore, J., Mandel, L., Splichal, I., Bianchi, A. T. J., Kovaru, F. \& Tlaskalova-Hogenova, H. (1996). Thymic B cells of pig fetuses and germ-free pigs spontaneously produce $\operatorname{IgM}, \operatorname{IgG}$ and $\operatorname{IgA}$ : detection by ELISPOT method. Immunology 87, 487-492.

Curtis, J. \& Bourne, F. J. (1971). Immunoglobulin quantitation in sow serum, colostrum and milk and the serum of young pigs. Biochimica et Biophysica Acta 236, 319-332.

Damm, B. I., Friggens, N. C., Nielsen, J., Ingvartsen, K. L. \& Pedersen, L. J. (2002). Factors affecting the transfer of porcine parvovirus antibodies from sow to piglets. Journal of Veterinary Medicine. A, Physiology, Pathology, Clinical Medicine 49, 487-495.

Demecková, V., Kelly, D., Coutts, A. G. P., Brooks, P. H. \& Campbell, A. (2002). The effect of fermented liquid feeding on the faecal microbiology and colostrum quality of farrowing sows. International Journal of Food Microbiology 79, 85-97.

De Passillé, A. M. B. \& Rushen, J. (1989). Using early suckling behavior and weight gain to identify piglets at risk. Canadian Journal of Animal Science 69, 535-544.

De Passille, A. M. B., Rushen, J. \& Pelletier, G. (1988). Sucking behaviour and serum immunoglobulin levels in neonatal piglets. Animal Production 47, 447-456.

De Passillé, A. M. B., Rushen, J., Foxcroft, G. R., Aherne, F. X. \& Schaefer, A. (1993). Performance of young pigs : relationship with periparturient progesterone, prolactin and insulin of sows. Journal of Animal Science 71, 179-184.

Devillers, N., Van Milgen, J., Prunier, A. \& Le Dividich, J. (2004). Estimation of colostrum intake in the neonatal pig. Animal Science 78, 305-313.

Devillers, N., Le Dividich, J., Farmer, C., Mounier, A. Z. M., Lefebvre, M. \& Prunier, A. (2005). Origin and consequences of the variability of colostrum production by the sow and of its intake by piglets. Journées de Recherches Porcine en France 37, 435-442.

Drew, M. D. \& Owens, B. D. (1988). The provision of passive immunity to colostrum-deprived piglets by bovine or porcine serum immunoglobulins. Canadian Journal of Animal Science 68, 1277-1284.

Dyck, G. W. \& Swiestra, E. E. (1987). Causes of piglet death from birth to weaning. Canadian Journal of Animal Science 67, 543-547.
Edwards, S. A. (2002). Perinatal mortality in the pig: environmental or physiological solutions? Livestock Production Science 78, 3-12.

Edwards, S. A. \& Rooke, J. A. (1999). Effects of management during the suckling period on post-weaning performance of pigs. In Proceedings of the 50th Annual Meeting of the European Association of Animal Production, Zurich, Switzerland, p. 166.

Eкström, G. M. \& Weström, B. R. (1991). Cathepsin B and $\mathrm{D}$ activities in intestinal mucosa during postnatal development in pigs. Relation to intestinal uptake and transmission of macromolecules. Biology of the Neonate 59, 314-321.

Elliot, J. I. \& Lodge, G. A. (1977). Body composition and glycogen reserves in the neonatal pig during the first 96 hours postpartum. Canadian Journal of Animal Science 57, 141-150.

Estienne, M. J., Harper, A. F., Barb, C. R. \& Azain, M. J. (2000). Concentrations of leptin in serum and milk from lactating sows differing in body condition. Domestic Animal Endocrinology 19, 275-280.

Farmer, C., Peticlerc, D., Sorensen, M. T., Vignola, M. \& Dourmad, J. Y. (2004). Impacts of dietary protein level and feed restriction during prepuberty on mammogenesis in gilts. Journal of Animal Science 82, 2343-2351.

Filipp, D., Alizadeh-Khiavi, K., Richardson, C., Palma, A., Paredes, N., Takeuchi, O., Akira, S. \& Julius, M. (2001). Soluble CD14 enriched in colostrum and milk induces B cell growth and differentiation. Proceedings of the National Academy of Science 98, 603-608.

Fiorotto, M. L., Davis, T. A., Reeds, P. J. \& Burrin, D. G. (2000). Nonnutritive factors in colostrum enhance myofibrillar protein synthesis in the newborn pig. Pediatric Research 48, 511-517.

Fraser, D. \& Rushen, J. (1992). Colostrum intake by the newborn piglets. Canadian Journal of Animal Science $\mathbf{7 2}$, $1-13$.

GASkins, H. R. (1998). Immunological development and mucosal defence in the pig intestine. In Progress in Pig Science (Eds J. Wiseman, M. A. Varley \& J. P. Chadwick), pp. 81-102. Nottingham, UK: Nottingham University Press.

Gomez, G. G., Phillips, O. \& Goforth, R. A. (1998). Effect of immunoglobulin source on survival, growth and hematological and immunological variables in pigs. Journal of Animal Science 76, 1-7.

Harada, E., Sugiyama, A., Takeuchi, T., Sitizyo, K., Syuto, B., Yajima, T. \& Kuwata, T. (1999). Characteristic transfer of colostral components into cerebrospinal fluid via serum in neonatal pigs. Biology of the Neonate 76, 33-43.

Hartman, P. E. \& Holmes, M. A. (1989). Sow lactation. In Manipulating Pig Production II. Proceedings of the Australasian Pig Science Association (Eds J. L. Barnett \& D. F. Hennessy), pp. 72-79. Werribee, Australia: Australasian Pig Science Association.

Hemsworth, P. H., Winfield, C. G. \& Mullaney, P. D. (1976). A study of the development of the teat order in piglets. Applied Animal Ethology 2, 225-233.

Hendrix, W. F., Kelley, K. K., Gaskins, C. T. \& Hinrichs, D. J. (1978). Porcine neonatal survival and serum gamma globulins. Journal of Animal Science 47, 1281-1286.

Herpin, P., Le Dividich, J. \& Amaral, N. (1993). Effect of selection for lean tissue growth on body composition 
and physiological state of pig at birth. Journal of Animal Science 71, 2645-2653.

Herpin, P., Le Dividich, J., Hulin, J. C., Fillaut, M., De Marco, F. \& Bertin, R. (1996). Effect of level of asphyxia during delivery on viability at birth and early postnatal vitality of newborn pig. Journal of Animal Science 74, 2067-2076.

Herpin, P., Lossec, G., Schmidt, I., Cohen-Adad, F., Duchamp, C., Lefaucheur, L., Goglia, F. \& Lanni, A. (2002). Effect of age and cold exposure on morphofunctional characteristics of skeletal muscle in neonatal pig. Pflügers Archiv European Journal of Physiology 444, 610-618.

Herpin, P., Louveau, I., Damon, M. \& Le Dividich, J. (2005). Environmental and hormonal regulation of energy metabolism in early development of the pig. In Biology of Metabolism in Growing Animals (Eds D. G. Burrin \& H. Mersmann), pp. 345-366. New York: Elsevier.

Huang, S. C., Hu, Z. L., Haslerrapacez, J. \& Rapacz, J. (1992). Preferential mammary storage and secretion of immunoglobulin gamma (IgG) subclasses in swine. Journal of Reproductive Immunology 21, 15-28.

Inoue, T., Kitano, K. \& Inoue, K. (1980). Possible factors influencing immunoglobulin $\mathrm{G}$ concentration in swine colostrum. American Journal of Veterinary Research 41, $1134-1136$

Jensen, A. R., Elnif, J., Burrin, D. G. \& Sangild, P. T. (2001). Development of intestinal immunoglobulin absorption and enzyme activities in neonatal pigs is diet dependent. Journal of Nutrition 131, 3259-3265.

Kelley, K. W., Blecha, F. \& Regnier, J. A. (1982). Cold exposure and absorption of colostral immunoglobulins by neonatal pigs. Journal of Animal Science $\mathbf{5 5}$, 363-368.

King, R., Le Dividich, J. \& DunsheA, F. R. (1999). Lactation and neonatal growth. In A Quantitative Biology of the Pig (Ed. I. Kyriazakis), pp. 155-180. Wallingford, UK: CAB International.

KiriyAmA, H. (1992). Enzyme-linked immunosorbent assay of colostral IgG transported into lymph and plasma in neonatal pigs. American Journal of Physiology 263, R976-R980.

Klobasa, F. \& Butler, J. E. (1987). Absolute and relative concentrations of immunoglobulins $\mathrm{G}, \mathrm{M}$ and $\mathrm{A}$, and albumin in the lacteal secretions of sows of different lactation numbers. American Journal of Veterinary Research 48, 176-182.

Klobasa, F., Werhahn, E. \& Butler, J. E. (1981). Regulation of humoral immunity in the piglet by immunoglobulins of maternal origin. Research in Veterinary Science 31, 195-206.

Klobasa, F., Habe, F., Werhahn, E. \& Butler, J. E. (1985). Changes in the concentrations of serum IgG, IgA and IgM of sows throughout the reproductive cycle. II. The influence of age and breed on the concentrations of serum $\mathrm{IgG}, \mathrm{IgA}$ and $\operatorname{IgM}$ in sows throughout the reproductive cycle. Veterinary Immunology and Immunopathology $\mathbf{1 0}$, 355-366.

Klobasa, F., Butler, J. E., Werhahn, E. \& Habe, F. (1986). Maternal-neonatal immunoregulation in swine. II. Influence of multiparity on de novo immunoglobulin synthesis by piglets. Veterinary Immunology and Immunopathology 11, 149-159.
Klobasa, F., Werhahn, E. \& Butler, J. E. (1987). Composition of sow milk during lactation. Journal of Animal Science 64, 1458-1466.

Klobasa, F., Schröder, C., Stroot, C. \& Henning, M. (2004). Passive immunization in neonatal piglets in natural rearing-effects of birth order, birth weight, litter size and parity. Berliner und Munchener Tierarztliche Wochenschrift 117, 19-23.

Knol, E. F., Leenhouwers, J. L. \& Van Der Lende, T. (2002). Genetic aspects of piglet survival. Livestock Production Science 78, 47-55.

Krakowski, L., Krzyzanowski, J., Wrona, Z., Kostro, K. \& Siwicki, A. K. (2002). The influence of nonspecific immunostimulation of pregnant sows on the immunological value of colostrum. Veterinary Immunology and Immunopathology 87, 89-95.

LeCCE, J. G. (1966). Glucose milliequivalents eaten by the neonatal pig and cessation of intestinal absorption of large molecules (closure). Journal of Nutrition 90 , 240-244.

Lecce, J. G. \& Morgan, D. O. (1962). Effect of dietary regimen on cessation of intestinal absorption of large molecules (closure) in the neonatal pig and lamb. Journal of Nutrition 78, 263-268.

Lecce, J. G., Morgan, D. O. \& Matrone, G. (1964). Effect of feeding colostral and milk components on the cessation of large molecules (closure) in neonatal pigs. Journal of Nutrition 84, 43-48.

Le Dividich, J. \& Noblet, J. (1981). Colostrum intake and thermoregulation in the neonatal pig in relation to environmental temperature. Biology of the Neonate 40, $167-174$.

Le Dividich, J. \& Noblet, J. (1984). Effects of colostrum intake on metabolic rate and plasma glucose concentration in the neonatal pig in relation to environmental temperature. Biology of the Neonate 46, 98-104.

Le Dividich, J., Herpin, P. \& Rosario-Ludovino, R. (1994). Utilization of colostral energy by the newborn pig. Journal of Animal Science 72, 2082-2089.

Le Dividich, J., Herpin, P., Paul, E. \& Strullu, F. (1997). Effect of fat content in colostrum on voluntary colostrum intake and fat utilization in the newborn pig. Journal of Animal Science 75, 707-712.

Le Dividich, J., Noblet, J., Herpin, P., Van Milgen, J. \& Quiniou, N. (1998). Thermoregulation. In Progress in Pig Science (Eds J. Wiseman, M. A. Varley \& J. P. Chadwick), pp. 229-263. Nottingham, UK: Nottingham University Press.

Le Dividich, J., Martineau, G. P., Thomas, F., Demay, H., Renoult, H., Homo, C., Boutin, D., Gaillard, L., Surel, Y., Bouétard, M. \& Massard, M. (2004). Acquisition of passive immunity in the piglets and production of colostrum by the sow. Journées de Recherches Porcine en France 36, 451-456.

Le Dividich, J., Thomas, F., Renoult, H. \& Oswald, I. (2005). Acquisition of passive immunity in the piglet: Effects of the amount of ingested immunoglobulins and of intestinal permeability. Journées de Recherches Porcine en France 37, 443-448.

Mahan, D. C. \& Peters, J. C. (2004). Long-term effects of dietary organic and inorganic selenium sources and levels on reproducing sows and their progeny. Journal of Animal Science 82, 1343-1358. 
Mahan, D., Kim, Y. Y. \& Stuart, R. L. (2000). Effect of vitamin E sources (RRR- or all-rac-alpha-tocopheryl acetate) and levels on sow reproductive performance, serum, tissue, and milk alpha-tocopherol contents over a five-parity period, and the effects on the progeny. Journal of Animal Science 78, 110-119.

Marion, J. \& Le Dividich, J. (1999). Utilization of sow milk energy by the piglet. In Manipulating Pig Production VII (Ed. P. D. Cranwell), p. 254. Werribee, Australia: Australasian Pig Science Association.

Mavromichalis, I., Parr, T. M., Gabert, V. M. \& Baker, D. H. (2001). True ileal digestibility of amino acids in sow's milk for 17-day-old- pigs. Journal of Animal Science 79, 707-713.

Mehrazar, K., Gilman-Sachs, A. \& Kim, Y. B. (1993). Intestinal absorption of immunologically intact macromolecules in germfree colostrum-deprived piglets maintained on total parenteral nutrition. Journal of Parenteral and Enteral Nutrition 17, 8-15.

Mellor, D. J. \& Cockburn, F. (1986). A comparison of energy metabolism in the newborn infant, piglet and lamb. Quarterly Journal of Experimental Physiology 71, 361-371.

Mellor, D. J. \& Murray, L. (1985). Effects of maternal nutrition on udder development during late pregnancy and on colostrum production in Scottish ewes with twin lambs. Research in Veterinary Science 39, 230-234.

Milon, A., Aumaitre, A., Le Dividich, J., Frantz, J. \& Metzger, J. J. (1983). Influence of birth prematurity on colostrum composition and subsequent immunity of piglets. Annales de Recherches Veterinaire 14, 533-550.

Noblet, J. \& Etienne, M. (1987). Body composition, metabolic rate and utilization of milk nutrients in suckling piglets. Reproduction Nutrition Development 27, 829-839.

Noblet, J. \& Le Dividich, J. (1981). Energy metabolism of the newborn pig during the first $24 \mathrm{~h}$ after birth. Biology of the Neonate 40, 175-182.

Patt, J. A. J. \& Eberhardt, R. J. (1976). Effects of metapyrone and ACTH on intestinal absorption of immunoreactive bovine $\mathrm{IgG}$ in caesarian-derived pigs. American Journal of Veterinary Research 37, 1409-1413.

Pattinson, S. E. \& Thomas, E. W. (2004). The effect of sire breed on colostrum production of crossbred ewes. Livestock Production Science 86, 47-53.

Pattinson, S. E., Davies, D. A. R. \& Winter, A. C. (1995). Changes in the secretion rate and production of colostrum by ewes over the first $24 \mathrm{~h}$ post partum. Animal Science 61, 63-68.

Payne, L. C. \& Marsh, C. L. (1962). Absorption of gamma globulin by the small intestine. Federation Proceedings 21, 909-912.

Pierce, A. E. \& Smith, M. W. (1967). The intestinal absorption of pig and bovine immune lactoglobulin and human serum albumin by the new-born pig. Journal of Physiology 190, 1-18.

Pinelli-SaAvedra, A. (2003). Vitamin E in immunity and reproductive performance in pigs. Reproduction Nutrition Development 43, 397-408.

Porter, P. \& Hill, I. R. (1970). Serological changes in immunoglobulins $\operatorname{IgG}, \operatorname{IgA}$ and $\operatorname{IgM}$ and Escherichia coli antibodies in the young pig. Immunology 18, 565-573.

Puchal, A. A. \& Buddington, R. K. (1992). Postnatal development of monosaccharide transport in pig intestine. American Journal of Physiology 262, G895-G902.
Reinhart, G. A., Simmen, F. A., Mahan, D. C., Simmen, R. C. M., White, M. E. \& Trulzsch, D. V. (1992). Perinatal ontogeny of fatty acid protein binding activity in porcine small intestine. Nutrition Research 12, 1345-1356.

RoOKe, J. A. \& Bland, I. M. (2002). The acquisition of passive immunity in the new-born piglet. Livestock Production Science 78, 13-23.

Rooke, J. A., Bland, I. M. \& Edwards, S. A. (1998). Effect of feeding tuna oil or soybean oil as supplements to sows in late pregnancy on piglet tissue composition and viability. British Journal of Nutrition 80, 273-280.

Rooke, J. A., Carranca, C., Bland, I. M., Sinclair, A. G., Ewen, M., Bland, V. C. \& Edwards, S. A. (2003). Relationship between passive absorption of immunoglobulin $\mathrm{G}$ by the piglet and plasma concentrations of immunoglobulin G at weaning. Livestock Production Science 81, 223-234.

Sangild, P. T., Diernaes, L., Christiansen, I. J. \& Skadhauge, E. (1993). Intestinal transport of sodium, glucose and immunoglobulin in neonatal pigs. Effects of glucocorticoids. Experimental Physiology 78, 485-497.

Sangild, P. T., Holtug, K., Diernaes, L., Schmidt, M. \& Skadhauge, E. (1997). Birth and prematurity influence intestinal function in the newborn piglet. Comparative Biochemistry and Physiology 118A, 359-361.

Sangild, P. T., Trahair, J. F., Loftager, M. K. \& Fowden, A. L. (1999). Intestinal macromolecule absorption in the fetal pig after infusion of colostrum in utero. Pediatric Research 45, 595-602.

Sangild, P. T., Fowden, A. L. \& Trahair, J. F. (2000). How does the foetal gastrointestinal tract develop in preparation for enteral nutrition after birth. Livestock Production Science 66, 141-150.

Schmidt, I. \& Herpin, P. (1998). Carnitine palmitoyltransferase 1 (CPT-1) activity and its regulation by malonyl-CoA are modulated by age and cold exposure in skeletal muscle mitochondria from newborn pigs. Journal of Nutrition 128, 886-893.

Schnulle, P. M. \& Hurley, W. L. (2003). Sequence and expression of the FcRn in the porcine mammary gland. Veterinary Immunology and Immunopathology $\mathbf{9 1}$, 227-231.

Smith, M. W. \& JARvis, L. G. (1978). Growth and cell replacement in the new-born pig intestine. Proceedings of the Royal Society of London B 203, 69-89.

Smith, M. W. \& Peacock, M. A. (1980). Anomalous replacement of foetal enterocytes in the neonatal pig. Proceedings of the Royal Society of London B 206, 411-420.

Speer, V. C., Brown, H., Quinn, L. Y. \& Catron, D. V. (1957). Antibody absorption in the baby pig. Journal of Animal Science 16, 1046-1047.

Svendsen, L. S., Weström, B. R., Svendsen, J., Ohlsson, B. G., Ekman, R. \& Karlsson, B. W. (1986). Insulin involvement in intestinal macromolecular transmission and closure in neonatal pigs. Journal of Pediatric Gastroenterology and Nutrition 5, 299-304.

Thompson, B. K. \& Fraser, D. (1988). Variation in piglets weights: weight gains in the first days after birth and their relationship with later performance. Canadian Journal of Animal Science 68, 581-590.

Tlaskalova-Hogenova, H., Mandel, L., Trebichavasky, I., Kovaru, F., Barot, R. \& Sterzl, J. (1994). Development 
of immune responses in early pig ontogeny. Veterinary Immunology and Immunopathology 43, 135-142.

Trayhurn, P., Temple, N. J. \& van Aerde, J. (1989). Evidence from immunoblotting studies on uncoupling protein that brown adipose tissue is not present in the domestic pig. Canadian Journal of Physiology and Pharmacology 67, 1480-1485.

Tuboly, S., Bernath, S., Glavits, R. \& Medveczky, I. (1988). Intestinal absorption of colostral lymphoid cells in newborn piglets. Veterinary Immunology and Immunopathology 20, 75-85.

Tuchscherer, M., Puppe, B., Tuschscherer, A. \& Tieman, U. (2000). Early identification of neonates at risk: traits of newborn piglets with respect to survival. Theriogenology 54, 371-388.

Tuchscherer, M., Kanitz, E., Otten, W. \& Tuchserer, A. (2002). Effects of prenatal stress on cellular and humoral immunity in neonatal pigs. Veterinary Immunology and Immunopathology 86, 195-203.

Varley, M. A., Maitland, A. \& Wilkinson, R. G. (1985). The survival of piglets given different amounts of colostrum after birth in relation to their plasma immunoglobulin status. Animal Production 40, 547-548.

Varley, M. A., Maitland, A. \& Towle, A. (1986). Artificial rearing of piglets: the administration of two sources of immunoglobulins after birth. Animal Production 43, $121-126$

Weary, D. M., Pajor, E. A., Thompson, B. K. \& Fraser, D. (1996). Risky behaviour by piglets: a trade off between feeding and risk of mortality by maternal crushing? Animal Behaviour 51, 619-624.

Werhahn, E., Klobasa, F. \& Butler, J. E. (1981). Investigation of some factors which influence the absorption of $\operatorname{IgG}$ by the neonatal piglet. Veterinary Immunology and Immunopathology 2, 35-51.

Weström, B. R., Ohlsson, B. G., Svendsen, J., Tagesson, C. \& Karlsson, B. W. (1985). Intestinal transmission of macromolecules (BSA and FITC-dextran) in the neonatal pig: enhancing effect of colostrum, protein and proteinase inhibitors. Biology of the Neonate 47, 359-366.

Williams, P. P. (1993). Immunomodulating effects of intestinal absorbed maternal colostral leukocytes by neonatal pigs. Canadian Journal of Veterinary Research 57, 1-8.

Wu, G., Оtт, T. L., Knabe, D. A. \& Bazer, F. W. (1999). Amino acid composition of the fetal pig. Journal of Nutrition 129, 1031-1038.

Xu, R. J., Sangild, P. T., Zhang, Y. Q. \& Zhang, S. H. (2002). Bioactive compounds in porcine colostrum and milk and their effects on intestinal development in neonatal pigs. In Biology of the Intestine in Growing Animals (Eds R. Zabielski, P. C. Gregory \& B. Weström), pp. 169-192. Amsterdam. Netherlands: Elsevier.

Zhou, Q., He, R. G., Li, X. \& Liao, S. R. (2003). Protease inhibitors in porcine colostrum: Potency assessment and initial characterization. Asian Australasian Journal of Animal Sciences 16, 1822-1829. 